\title{
RELATIONSHIP BETWEEN THE PREVALENCE OF ANTIBODIES TO ARBOVIRUS AND HEPATITIS B VIRUS IN THE VALE DO RIBEIRA REGION, BRAZIL.
}

Claudio Sergio PANNUTI (1, 3), Lygia Busch IVERSSON (2), Joăo Silva de MENDONCA (3), Amelia P. A. TRAVASSOS DA ROSA (4) \& Celso Francisco Hernandes GRANATO (5).

\begin{abstract}
SUMMARY
280 students, between 6 and 14 years old, residents in the Iguape county, southern coast of the State of Sao Paulo, were studied in order to identify the existence of a possible association between the prevalence of specific antibodies to the hepatitis $B$ virus and the exposure to haematophagous mosquitoes, evaluated indirectly through the prevalence of antibodies to 17 arboviruses isolated in Brazil.

The children were from 4 areas with different topographical characteristics: 89 of the children were from the urban zone of the town of Iguape, 89 were from the peri-urban zone. 30 were from the rural area with extensive banana plantations. and 72 were from the jungle zone. Previous studies had shown significantly higher prevalence of antibodies to different arboviruses in the cultivated zone and the jungle zone. when compared to the urban and peri urban zones of Iguape. The detec tion of antibodies to the HBV surface antigen (HBs Ag! was done through the radioimmunoassay (Ausab, Abbott Laboratory). The cases considered positive were confirmed through the presence of anti-core HBV antibodies (anti HBC. EIA Roche).

A significantly higher prevalence of anti $\mathrm{HBV}$ antibodies was observed in chil. dren from the jungle zone $2672=36.1 \%$, when compared to those from the urban zone $1589=5.6 \%$, peri urban $1689=6.7 \%)$ or from the cultivated zone $1030=$ $0 \% 1$.

The result suggest the existence of a common factor in the dissemination of the arboviruses and the hepatitis B virus, supporting the hypothesis that mosquitoes may play an important role in the HBV transmission in tropical forested region.
\end{abstract}

KEY WORDS: Hepatitis B transmission: Hepatitis B seroepidemiology. Arbovirus and Hepatitis $B$

\section{INTRODUCTION}

The higher prevalence of hepatitis $B$ virus (HBV) markers in human populations in tropical regions ${ }^{3 .}{ }^{34}$ suggested that, along with conven tional transmission mechanisms observed in

\footnotetext{
11. Instituto de Medicina Tropical e LIM do Hospital das Clinicas da Faculdade de Medicina da Universidade de San Paulo. Sào Paulo. SP. Brasil.

(2) Faculdade de Saude Publica da Universidade de Sao Paulo, Sao Paulo, SP, Brasil

(3) Hospital do Servidor Publico do Estado de Sào Paulo. Sao Paulo. SP. Brasil.

(4) Instituto Evandro Chagas. Ministerio da Saude. Belem. Para Brasil.

(5) Instituto Adolfo Lutz. Secretaria do Estado da Saude de Sao Paulo. Sáo Paulo, SP. Brasil
}

Address for correspondence: Dr. Cládio Sergio Pannuti. Instituto de Medicina Tropical de Sáo Paulo. Av. Dr. Eneas de Carvalho Aruiar. $470 \quad 05403$ sá Paulo. SP. Brasil 
PANNUTI, C. S.; IVERSSON, L. B; MENDONÇA, J. S. de: TRAVAsSOS DA ROSA, A. P. A. \& GRANATO, C. F. H. - Relationship between the prevalence of antibodies to arbovirus and hepatitis B virus in the Vale do Ribeira region, Brazil. Rev. Inst. Med. trop. Sáo Paulo, 31 (2): 103-109, 1989.

other parts of the world, additional modes of transmission might be present in the tropics.

The high prevalence in some of these regions of diseases transmitted by haematophagous arthropods and the low frequency of blood trans. fusion or injections among their inhabitants, raised the first suspicion of $\mathrm{HBV}$ transmission via mosquitoes and other insects as reported by BLUMBERG et al. ${ }^{4}$. Detection of HB Ags in various species of mosquitoes and other haematophagous arthropods captured in tropical regions ${ }^{6}$. $8,17,27,35,40,41,42$ and even urban areas of the United States ${ }^{13}$, has somehow corroborated this hypothesis. Experimental studies showed that when various species of mosquitoes ${ }^{2}$ 6. 7. 28.30. 31,38 and other haematophagous arthropods ${ }^{12,26 .}$ 31. 37. 39. 40 were fed blood containing HBs Ag, it was possible to detect this marker in mosquitoes for approximately up to 4 days, in most of the studies, and for periods up to several weeks in the other arthropods. It was observed, however, that the HBs Ag disappears once the blood is fully digested, indicating that no viral replication occurred in the animal $\mathrm{l}^{6,7,31}$.

According to these results, infections of $\mathrm{HBV}$ via arthropods would be the result of mechanical transmission. In this mode of transmission, which was already been described for several types of plant and animal viruses, such as the myxoma virus in rabbits and certain arboviruse ${ }^{11}$, the virus would remain viable in the structure of the sucking apparatus of the arthropods and might be transmitted passively from a contaminated host to a susceptible one, of the refeeding time for the mosquito, or when it completed a feeding which had been interrupted ${ }^{5}$. As is the case with certain viruses such as the Venezuelan equine encephalitis ${ }^{11}$ or Rift Valley fever viruses which reach very high concentration in blood: the likehood of mechanical transmission of HBV, which is highly infectious and highly resistant to inativation ${ }^{36}$, appears possible.

This mechanical transmission should occur more frequently in tropical regions, where there is intensive the activity of haematophagous arthropods.

A seroepidemiologic survey to $\mathrm{HBV}$, carried out in São Paulo State, Brazil ${ }^{29}$, demonstrated an unusually high prevalence of anti-HBS among children living in a camping area near Serra do Mar, a rural area near the coastal region of the State. The study showed a prevalence of $31.2 \%(10 / 32)$ among children whose age ranged from 1 to 5 years, and $48.7 \%$ (19/39) among those in the 6 to 11 years group. These children were of low socioeconomical status. However, among the adult population of low socioeconomic status living in the urban area of the city of Sāo Paulo, the prevalence of anti-HBs was only $14.58 \% \%^{29}$, suggesting that factors other than the socioeconomic status determined, the high prevalence of immunological markers to $\mathrm{HBV}$ in this locality.

In order to test the hypothesis that wild culicidae might be involved in $\mathrm{HBV}$ transmission, a seroepidemiologic survey to the $\mathrm{HBV}$ was conducted in a region with similar ecological characteristics, namely the Vale do Ribeira, which is also included in the so called Serra do Mar Sys tem. This area is characterized by an abundant Culicidae fauna ${ }^{15 .}{ }^{16}$. Since 1977 the Department of Epidemiology of the Public Health School of the University of São Paulo, in collaboration with Evandro Chagas institute, has conducted seroepidemiological surveys for arboviruses in the human population. The prevalence of arbovirus an tibodies should thus provided an indirect indi cator of the risk of infections transmitted by mosquitoes. The prevalence of immunological markers of the HBV should be correlated with that of arbovirus antibodies.

\section{MATERIAL AND METHODS}

THE AREA. The serological survey was car ried out in Iguape, one of the counties of the Vale do Ribeira, located in the coastal area of the State of São Paulo, southeast Brazil, in a region still extensively covered by forests.

In 1976 an epidemic of arbovirus encephalitis resulted in a morbidity index of $717.5 / 100.000$ inhabitants in Iguape ${ }^{21}$. Seroepide miological studies showed that arbovirus as be longing to the Togaviridae and Flaviviridae families, pathogenic for human ${ }^{22-25}$, are circulating in the region.

Within the limits of the county, four areas with different topographical and phytological 
PANNUTI, C. S.: IVERSSON, L. B.: MENDONÇA, J. S. de; TRAVAssos DA ROSA, A. P. A. \& GRANATO, C. F. H. - Relationship between the prevalence of antibodies to arbovirus and hepatitis $B$ virus in the Vale do Ribeira region, Brazil. Rev. Inst. Med. trop. São Paulo, 31 (2): 103 109, 1989

characteristics, were studied. These areas, have been described in details previously ${ }^{25}$. They are briefly:

a) Urban Zone: including Iguape, a town located in the coast and a health resort in a large neighbouring island, which presents urban structure;

b) Peri-Urban Zone: Rocio District, in the outshirts of Iguape, with rural characteristics, poor houses sparsely located among the vegetation; grass and small bushes predominate.

c) Cultivated Zone: in the coastal plains, with a few areas of residual forest. Extensive planting of bananas, and, more recently, of vegetables and grain, is carried out.

d) Jungle Zone: still extensively covered by forests, made up of tall trees, dense foliage and high degree of heterogenity, where the utiliza tion of land agricultural and cattle-raising purposes is still limited.

\section{CASE STUDY}

In the 1981-1982 period, blood samples were collected for an arbovirus seroepidemiological study from 337 students ( 6 to 14 years old) from Iguape county. These children proved to have different prevalences of $\mathrm{HI}$ antibodies to 17 arbovirus isolated in Brazil, according to the locality where they lived. Among. these 337 sera, preser. ved at $-20 \mathrm{C}, 280$ presented an enough amount that permited the research of HBV immunological markers. The 280 children resided in diffe rent areas: 89 of them lived in the Urban Zone; 89 in the Periurban Zone, 30 in the Cultivated Zone and 72 in the Jungle Zone. The majority of the children $(70.1 \%)$ had lived all their lives in the place at which they were residing at the time of the study. Only $2.8 \%$ had lived there for a period of less than one year. The 280 children belonged to 233 different families. In 33 families two or more children were examined.

Socioeconomic status was estimated on the basis of the father's profession, and proved to be low, with no significant difference between the areas of residences, since $71(30.5 \%)$ of the fathers were agricultural workers, $58(24.9 \%)$ were manual laborers, $27(11.6 \%)$ were fishermen $27(11.6 \%)$ were low level public servants, $13(5.6 \%)$ were clerks in commercial establishments, and $4(1.7 \%)$ were elementary schoolteachers. In 33 cases $(14.2 \%)$ this information was not available. As to sex, 51.7\% $(135 / 261)$ were male and 48.3 (126/261) were female. In 19 cases, this informa tion was not available.

Anti-HBs Ag was determined by radioimmunoassay (Ausab-Abbott Laboratories).

The positive sera were tested to anti-HBc antibodies by an immunoenzimatic technique (Roche Laboratory). To ensure accuracy in the results, only cases where both markers were present were considered positive. In schoolchildren from the Cultivated Zone anti-HBc antibodies were measured in all sera.

\section{RESULTS}

Of the 280 sera studied, $37(13.2 \%)$ were posi tive for anti-HBs. A prevalence of $27 / 71(38.0 \%)$ was presented by children of farm workers, $3 / 27$ $(11.1 \%)$ by children of fishermen and $7 / 135(5.2 \%)$ by children whose fathers worked at others acti vities. As to sex there was no significant difference $(\mathrm{p}>0.05)$ between prevalence in male $(12.6 \%)$ and female $(15.1 \%)$. In one of the positive cases, this information was not available. As to age distribution, no statistically significant difference $(\mathrm{p}>0.05)$ was observed in the prevalence of anti-HBs Ag antibodies among the groups of 6 to 8 years $(11.8 \%), 9$ to 11 years $(13.3 \%)$ and 12 to 14 years $(16.0 \%)$.

The prevalence rates of anti-HBs Ag and ar bovirus antibodies according to the four diffe rent geographic areas considered may be seen in Table 1. In the Jungle area, the rate of sera with positive anti-HBs was $36.1 \%(26 / 72)$, signifi cantly higher than other zones $(p<0.001$ ). In the three localities of this Jungle area, preva lence was $36 \%(9 / 25)$ in the Pavoa district, $37.8 \%$ (14/37) in the Pé da Serra district, and $30 \%(3 / 10)$ in the Despraiado district.

None of the cases from the Bananal Zone presented anti-HBc or anti-HBs antibodies.

When we only considered the families where no more than one child was studied, the anti 
PANNUTI, C. S.: IVERSSON, L. B.: MENDONCA. J. S. de: TRAVASSOS DA ROSA, A. P. A. \& GRANATO. C. F H. - Relationship between the prevalence of antibodies to arbovirus and hepatitis $B$ virus in the Vale do Ribeira region, Brazil. Kev. Inst. Med. trop. Sāo Paulo, 31 12 : 103 109, 1989.

HBs prevalences were of $26.7 \%$ in the Jungle $\mathrm{Zo}$ ne. $8.2 \%$ in the Periurban Zone and $6.1 \%$ in Ur ban Zone showing a significant difference bet ween Jungle Zone and Urban and Periurban $\mathrm{Zo}$ nes $\left(\mathrm{X}^{2}=10.5050 \mathrm{p}<0.01\right)$.

\section{DISCUSSION}

There are significant differences in the pre valence of HBs antibodies according to the geo graphic area considered. The prevalence of

\section{TABLE 1}

Prevalence of HBs Ag antibodies (anti-Ags HB) and HI antibodies against 17 arbovirus in school children, aged 6 to 14 years, for different areas of Vale do Ribeira, São Paulo, Brazil.

\begin{tabular}{|c|c|c|c|}
\hline Geographic area & $\begin{array}{c}\mathrm{N} \\
\text { tested }\end{array}$ & $\begin{array}{l}\text { N:positive }(\%) \\
\text { Anti-HBs Ag }\end{array}$ & $\begin{array}{l}\mathrm{N}: \text { positive }(\%) \\
\text { Anti-arbovirus }\end{array}$ \\
\hline $\begin{array}{c}\text { Urban Zone } \\
\text { (Iguape and Ilha Comprida) }\end{array}$ & 89 & $5(5.6 \%)$ & $2(2.2 \%)$ \\
\hline $\begin{array}{l}\text { Periurban Zone } \\
\text { (Rocio) }\end{array}$ & 89 & $6(6.7 \%)$ & $3(3.4 \%)$ \\
\hline Cultivated Zone & 30 & $0(0.0 \%)$ & $7(23.3 \%)$ \\
\hline Jungle Zone & 72 & $26(36.1 \%)$ & $13(18.0 \%)$ \\
\hline Total & 280 & $37(13.2 \%)$ & $25(8.9 \%)$ \\
\hline
\end{tabular}

$36.1 \%$ in children from 6 to 4 years old, the vast majority of whom $(73 \%)$ were children of farmers who lived in the Jungle Zone, is unusual, both in relation to children from other areas of the present study and in relation to the rates obser ved in the adult population of low socioeconomic status in the city of São Paulo, where the prevalence of anti-HBs antibodies was $14.58 \%$. The rates were similar to those of high prevalence $(48.7 \%)$ observed in 6 to 11 year-old children living in the Serra do Mar region ${ }^{29}$, also in the southern coast of Sāo Paulo State, which presents climatic and phytological conditions similar to those of the Vale do Ribeira.

In the present study, the children had a homogeneous socioeconomical status. Also, there were no significant differences as to sex and age of those infected by HBV ( $p>0.05$ ). Thus, it is probable that a factor linked to the geographic area could be influencing the larger dissemination of the HBV in the Jungle Zone. The fact that similar rates were found in three different localities of the Jungle Zone somehow removes the possi- bility of a local epidemic of infection by $\mathrm{HBV}$. since these populations have almost no contact at all among themselves. Besides even we exclude 33 families where two or more children were studied (15 from Jungle zone), the prevalence of positive sera to anti-HBs antibodies remains significantly higher in the Jungle Zone than other areas.

Previous study, carried out among these very same children, also detected a clear pattern in the prevalence of $\mathrm{HI}$ antibodies to 17 arboviruses in Brazil, depending on the geographical area under consideration ${ }^{25}$. The prevalence of arbovirus antibodies was significantly higher among those living in the rural zone (Jungle and Cultivated Zones) than observed among chil dren living in the Urban and Peri-Urban Zones ${ }^{25}$.

The results suggest the existence of a com mon factor in the dissemination of $\mathrm{VHB}$ and of the arboviruses in forested areas, one of the possibilities being that of transmission by means 
PANNUTI, C. S.: IVERSSON. L. B: MENDONÇA, J. S. de: TRAVAsSOS DA ROSA. A. P. A. \& GRANATO. C. F. $\mathrm{H}$. - Relationship between the prevalence of antibodies to arbovirus and hepatitis $B$ virus in the Vale do Ribeira region, Brazil. Rev. Inst. Med. trop. São Paulo, 31 (2): 103-109, 1989

of anthropophilic mosquitoes, extremely abundant in that region ${ }^{15,16}$.

Nevertheless, the transmission mecha nisms for both viruses would have totally different characteristics. Thus, is relation to the arboviruses, there is a continuous maintenance cy cle of these agents in the forest, with partici pation of wild vertebrates, especially mammals and birds, and of haematophagous mosquitoes in which the virus multiplies. When humans enter this ecosystem, they face a high probability of becoming infected. The HBV, on the other hand, would be mechanically transmitted by haematophagous arthropods; this requires, besides the high density of this arthropods, exogenous intro duction of the virus by infected humans. This might occur in one area and not in another, even though the second area might be just a few kilometers away from the first, due to the fact that this transmission depends on the degree of dispersion of the mechanical vectors. Furthermore, there are no know animal reservoirs to $\mathrm{HBV}$ except man. The association between the prevalence of arbovirus antibodies and anti-HBs, which seem to be directed proportional the higher the prevalence of anti-arbovirus antibodies, the higher the prevalence of anti-HBs Ag antibodies), is sharply interrupted in the Cultivated Zone, the very place of highest prevalence of arbovirus antibodies.

A reasonable explanation to this discrepancy $(0 \%$ of anti-HBs and $23,3 \%$ of arbovirus anti bodies) would be the total absence of $\mathrm{HBV}$ carriers in the Cultivated Zone. The total absence of HBV markers among children in this zone corroborates this hypothesis. Should $\mathrm{HBV}$ be intro duced in this locality, the expectation would be for an infection prevalence comparable to that of Jungle Zone since in the open areas of the extraforest environment of Iguape there is a high frequency of different species of Culicidae ${ }^{15}{ }^{16}$. Additional research directed to this area becomes necessary. In the Urban and Peri-Urban Zones of the town of the Iguape, the epidemiolo gical behavior would be equivalent to that observed in the Urban Zone of the city of São Paulo.

Other studies have attempted to stablish a correlation between $\mathrm{HBV}$ markers and the presence of mosquitoes ${ }^{1.14 .20 .32}$; the results are con- flicting. However, the different conditions under which these studies were carried out and the different techniques employed for the detection of $\mathrm{HBV}$ immunological markers make the comparison of the results difficult.

Unusually high prevalences of $\mathrm{HBV}$ immu nological markers have been consistently obser ved among Indian tribes in the western Ama zon area, varying, in the adult individuals from $60,7 \%$ to $100 \%{ }^{9} 10.18 .19$. As for inhabitants of the rural zone in the Vale do Ribeira these popula tions live in relative isolation, in close contact with the forest. High rates of infection by arbovirus, such as Mayaro, have also been observed in the Amazon region ${ }^{33}$. Even if there is a wide gap between the Indians of the Amazon regions and the inhabitants of the Vale do Ribeira area, both populations have something in common: they both live in close contact with the forest environment and its fauna. The present study seems to support the hypothesis that mosquitoes may play an important role in the transmission of hepatitis $B$ in the tropical forested regions, However, further research becomes ne cessary to shed further light on the matter.

\section{RESUMO}

\section{Relação entre prevalência de anticorpos para arbovirus e virus de hepatite $B$ na região do Vale do Ribeira, Brasil.}

280 escolares de 6 a 14 anos de idade, residentes em Iguape, Vale do Ribeira, sudeste do Estado de Sāo Paulo, foram estudados com o objetivo de verificar possível associação entre a preva lência de anticorpos para hepatite $\mathrm{B}$ e a exposição a mosquitos hematófagos, avaliada indire tamente pela prevalência de anticorpos de arbo vírus. As crianças eram originárias de 4 áreas com características topográficas e fitográficas diferentes: 89 residiam em área urbana, $89 \mathrm{em}$ área periurbana, 30 em área de cultivo extensivo de banana e hortaliças e 72 em área florestal. Estudos prévios mostraram significante maior prevalência de anticorpos de arbovírus nas áreas cultivada e florestal do que nas áreas urbana e periurbana. A pesquisa de anti-HBs foi feita por radioimunoensaio (Ausab, Laboratório Ab bott) e de anti-HBc por ensaio imunoenzimático (Roche). Observou-se que os escolares residentes 
PANNUTI, C. S.: IVERSSON, L. B.: MENDONÇA. J. S. de: TRAVASSOS DA ROSA, A. P. A. \& GRANATO. C. F H. - Relationship between the prevalence of antibodies to arbovirus and hepatitis $B$ virus in the Vale do Ribeira region, Brazil. Rev. Inst. Med. trop. São Paulo, 31 12): 103 109. 1989.

na área florestal apresentaram mais alta preva lência $(26 / 72=36.1 \%)$ de anticorpos para hepa tite $\mathrm{B}$ de que os residentes nas áreas urbana $(5 / 89$ $=5,6 \%)$, periurbana $(6 / 89=6.7 \%)$ e cultivada $10 / 30=0 \%)$. Os resultados sugerem a existéncia de fator comum na transmissão de arboviroses e de hepatite $B$, apoiando a hipótese que nas regiỏes tropicais com presença de mata mosqui tos possam desempenhar importante papel na transmissão da hepatite $\mathbf{B}$.

\section{REFERENCES}

1. BAYLET, R.; DIEBOLT, G.; LINHARD. J. \& DIOP. S - Fréquence de l'antigene Australia etudiee comparati vement a l'activité anophélienne dans sept villages serers au Sénégal. Bull. Soc. Path. exot., 67: 64.72, 1974

2. BERQUIST, K. R.: MAYNARD, J. E.: FRANCY, D. B : SHELLER. M. J.\& SCHABLE, C.A. -.- Experimental stu dies on the transmission of hepatitis $B$ by mosquitoes Amer. J. trop. Med. Hyg., 25: 730732.1976.

3. BLUMBERG, B. S. SUTNICK, A I \& LONDON, W. T - Hepatitis and leukemia: their relation to Australia anti gen. Bull. N. Y. Acad. Med., 44: 1566 1586, 1968.

4. BLUMBERG, B. S.: SUTNICK, A. I.: LONDON, W. T \& MILLMAN, I. ... Australia antigen and hepatitis. New Engl. J. Med., 283: 349354,1970 .

5. BOREHAM, P. F. J. \& GARRETT JONES, C. - Preva lence of $\mathrm{mixed}$ blood meals and double fecding in a mala ria vector (Anopheles sacharovi Favre). Bull. Wld. HIth. Org., 48: 605614,1973

6. BROTMAN, B.: PRINCE. A. M. \& GODFREY, H. R Role of arthropods in transmission of hepatitis $B$ virus in the tropics. Lancet, 1: 13051308,1973

7. BYRON, N, A : DAVIDSON, G.: DRAPER, C. C. \& ZUC KERMAN, A. J. - Role of mosquitoes in transmission of hepatitis B antigen. J. infect. Dis., 128: 259 260.1973.

8. CANDEIAS, J. A. N.; FORAT'TINI. O. P. \& VIEIRA, J G. - Evidenciaçà de antigeno da hepatite $B$ (HBS Ag) em "manchas" obtidas de exemplares de triatominae Rev. Saude públ., (S. Paulo), 10: 267268,1976

9 CARRILHO F, J \& SILVA, L C - Epidemiologia In SILVA, L. C. - Hepatites apudas e crónicas. Sào Paulo Sarvier, 1986 p. 4769

10. CASTPO E. J.: FARIAS, R H. G.: ROSA FILHO, S. M.: FRIAS, C. A.: ANDRADE, E. L. D.: SIMONETTI, S. R. R. \& SIMONETTI, J. P. - Prevaléncia dos marcadores dos virus $B$ e Delta em populaçào indigena da tribo Yano mani, AM. In: JORNADA LATINO AMERICANA DE HePatologia, 9. Sāo Paulo, Brasil, 1986. Anais. p 40 .
11. CHAMBERLAiN, R. W. \& SUDiA, W. D. - Mechanism of transmission of viruses by mosquitoes. Ann Rev. Entomol., 6: 371-390, 1961

12. COHEN, J : MANDOLESI. J. F.: LASZLO. M. \& ILLA NES, L. - El Triatoma infestans como vector del virus B de la hepatitis. Acta Gastroent. lat-amer., 11: 215-223. 1981

13. DICK, S. J.: TAMBURRO. C. H. \& LEEVY. C. M. - Hepa titis $\mathbf{B}$ antigen in urban caught mosquitoes. J. Amer. med. Ass., 229: 1627-1629, 1974

14. DIEBOLT, G : BLAVY, G : LAURENS, A ; DIEKHATE L. \& LINHARD, J. - Róle des insectes vecteurs dans la transmission de l'Ag HBs. Bull. Soc. med. Afr. Langue franç., 23: $270275,1978$.

15. FORATTini, O. P.: GOMES. A. de C.: GALATI, E. A B : RABELLO E. X \& IVERSSON, L B. - Estudos ecoló gicos sobre mosquitos Culicidae no Sistema da Serra do Mar. Brasil. I. Observaçōes no ambiente extradomiciliar. Rev. Saude publ. (S. Paulo), 12: 297-325, 1978.

16. FORATTINI, O. P: GOMES, A de C: SANTOS, J. L F.: GALATI, E. A. B.; RABELlo, E. X. \& NATAL, D - Observaçoes sobre atividade de mosquitos Culicidae em mata residual no Vale do Ribeira. Sao Paulo. Brasil. Rev. Saude publ. (S. Paulo), 15: $557586,1981$.

17. FORATTINI, O. P.; OTTATI, S. M.; CANDEIAS, J. A N.: VIEIRA. J. G. \& RACZ. M. L. - Evidenciacào do anti geno da hepatite B (HBs Ag) em triatominae. Rev. Saúde publ. (S. Paulo), 14: 194 198, 1980

18. FRANCO. V. S.: GUIMARAES, R. X :; FRANCO. L. J BARUZZI, R G. \& NOVO, N F. -- Marcadores sorologicos da hepatite viral $B$ e alfa 1 antitripsina em índios da tribo Mekranhotire. Rev paul. Med., 103: 223 227, 1985

19. GAYOTTO. L. C. C.: QUARENTEI. A. A. \& CABRAL G. L. - Soroepidemiologia das hepatites A e B nas regioes dos Rios Biá e Alto Juruá. Amazonia Ocidental. GED. 3: 106112,1984 .

20. HAWKES, R. A.: VALE, T. G.; MARSHALL, I. D. \& MA CLENNAN, R. - Constrasting seroepidemiology of Aus tralia antigen and arbovirus antibodies in New Guinea. Amer. J. Epidem., 95: 228.237, 1972

21. IVERSSON. L. B. - Aspectos da epidemia de encefalite por arbovirus na regiāo do Vale do Ribeira, Sāo Paulo. Brasil no período de 1975 a 1978 . Rev. Satide públ. (S. Paulo), 14: 9-35, 1980

22. IVERSSON, L. B.; TRAVASSOS DA ROSA, A. P. A. \& TRAVASSOS DA ROSA, J - Estudos sorológicos para pesquisa de anticorpos de arbovirus em populaçāo huma na da regiāo do Vale do $R$ ibeira. II. Inquérito em pacientes do Hospital Regional de Pariquera-Açu, 1980. Rev. Saude públ. (S. Paulo), 15: 587-602, 1981

23. IVERSSON, L. B.; TRAVASSOS DA ROSA, A. P. A TRAVASSOS DA ROSA, J.: ELEUTERIO, G. C. \& PRA DO. J. A. - Estudos sorológicos para pesquisa de anti corpos de arbovirus em populaçào humana da regiāo do Vale do Ribeira. I. Seguimento sorológico de grupo popu 
PANNUTI, C. S.; IVERSSON, L. B.; MENDONÇA, J. S. de: TRAVASSOS DA ROSA, A. P. A. \& GRANATO, C. F. H. - Relationship between the prevalence of antibodies to arbovirus and hepatitis $B$ virus in the Vale do Ribeira region, Brazil. Rev. Inst. Med. trop. Sāo Paulo, 31 (2): 103-109, 1989.

lacional residente em ambiente silvestre. In: SIMPOSIO INTERNACIONAL DE ARBOVIRUS DOS TROPICOS E FEBRES HEMORRÁGICAS, Belém, 1980. Anais. Rio de Janeiro, Academia Brasileira de Ciencias, 1982. p. $229-243$.

24. IVERSSON, L. B.: TRAVASSOS DA ROSA, A. P. A. TRAVASSOS DA ROSA, J. \& COSTA, C. S. - Estudos sorológicos para pesquisa de anticorpos de arbovírus em populaçāo humana da regiāo do Vale do Ribeira. III. In quérito em coabitantes com casos de encefalite por Flavivirus Rocio. Rev. Saude pub. (S. Paulo), 16: 160 170, 1982

25. IVERSSON, L. B.; TRAVASSOS DA ROSA. A. P. A. TRAVASSOS DA ROSA J.F. S., PINTO, G. H. \& MACE DO, O. - Estudos sorológicos para pesquisa de anticorpos de arbovirus em população humana da regiáo do Vale do Ribeira. IV. Inquérito em escolares residentes no muni. cipio de Iguape, São Paulo, Brasil. Rev. Saude públ. (S. Paulo), 17: 423-435, 1983

26. JUPP, P. G.: \& MC ELLIGOTT, S. E. - Transmission experiments with hepatitis $B$ surface antigen and the com mon bedbug (Cimex lectularius L). S. Afr. med. J., 56 $54-57,1979$

27. JUPP, P. G.; PROZESKY, O. W.: MC ELLIGOTT, S. E. \& VAN WYK, L. A. S. - Infection of the common bedbug (Cimex lectularius L) with hepatitis B virus in South Afri ca. S. Afr. med. J., 53: 598 600, 1978

28. LEEVY, C. M.; HOWARD, M. M; CRANS, W. J.; EVANS E. S. \& PRINCE. A. - Viral hepatitis and the mosquito. Gastroenterology, 62: 872, i 972

29. MENDONCA, J. S ; PANNUTI, C. S.; CARVALHO, M. J M.; OSELKA, G. W.; VILAS BOAS, L. S. \& AMATO NE TO, V. - Inquérito soroepidemiologico do virus da hepa tite B em São Paulo. In CONGRESSO DA SOCIEDADE BRASILEIRA DE MEDICINA TROPICAL, 19., Rio de Janeiro, 1983. p. 151

30. METSELAAR, D.: BLUMBERG. B. S.; MILLMAN, I PARKER.A. M \& BAGSHAWE. A. F. - Hepatitis B anti gen in colony mosquitoes. Lancet, 2: 758760,1973

31. NEWKIRK, M. M.; DOWNE, A. E. R. \& SIMON, J. B. Fate of ingested hepatitis $B$ antigen in blood-sucking in sects. Gastroenterology, 69: 982-987, 1975.

32. PAPAeVANGEloU, G. \& KOUREA-KREMASTINOU, T. - Role of mosquitoes in transmission of hepatitis B virus infection. J. infect. Dis., 130: 78 80, 1974.
33. PINHEIRO, F. B. - Situação das arboviroses na regiâo Amazónica. In: SIMPOSIO INTERNACIONAL SOBRE ARBOVIRUS DOS TROPICOS E FEBRES HEMORRAGICAS, Belém, 1980. Anais. Rio de Janeiro, Academia Brasileira de Ciencias, 1982. p. 27.48.

34. PRINCE, A. M. - Prevalence of serum hepatitis related antigen (SH) in different geographic regions. Amer, J. trop. Med. Hyg., 19: 872-879, 1970.

35. PRINCE, A. M.; MetSelaAk, D.; KAFUKO. G. W.: MUKWAYA. L. G.; LING, C. M. \& OVERBY, L. R. - Hepa titis $B$ antigen wild caught mosquitoes in Africa. Lancet. 2: $247-250,1972$.

36. REDEKER, A. G.; HOPKINS, C. E.; JACKSON, B. \& PECK, P. - A controlled study of the safety of pooled plasma stored in the liquid state at $30.32 \mathrm{C}$ for six months. Transfusion, 8: 60-64, 1968 .

37. ROSA, H.; LEMOS. Z. P.: PORTO. J. D.; ANDRADE SÁ, N. M.; RASSI, A. \& SANTANA. E. - Role of triatoma (Cone-nose bugs) in transmission of hepatitis B antigen. Rev. Inst. Med. trop. S. Paulo, 19: 310 312, 1977.

38. SMITH, J. A.; OGUNDA, E. O. \& FRANCIS. T I. - Trans mission of Australia Au (1) antigen by Culex mosquitoes. Nature, 237: 231.232, 1972

39. TAYLOR, P. \& MORRISON, J. - Cimex lectularius as a vector of hepatitis B. Cent. Afr. J. Med., 26: 198200 , 1980 .

40. VILLAREJOS, V. M: ZÚNIGA, A. \& GUTIERREZ, A. Possible role of haematophagous insects in the transmis sion of type B hepatitis. Trans. roy. Soc. trop. Med. Hy g., 69: 368 . 369, 1975

41. WILLS, W.: LONDON, W. T.: WERNER, B. G.: POUR TAGHVA, M.; LAROUZE, B : MILLMAN, I.; OGSTON, W.; DIALLO, S. \& BLUMBERG, B S. - Hepatitis B virus in bedbugs (Cimex hemipterus) from Senegal. Lancet, 2: 217219,1977

42. WILLS, W.: SAIMOT, G.: BROCHARD, C.: BLUMBERG B. S.; LONDON, W. T.; DECHENE, R. \& MILLMAN, I. - Hepatitis B surface antigen (Australia antigen) in mos quitoes collected in Senegal, West Africa. Amer. J. trop. Med. Hyg., 25: 186 190, 1976

Recebido para publicaçāo em 01/09/1988. 